\title{
Decoupling of calcification and photosynthesis in the coccolithophore Emiliania huxleyi under steady-state light-limited growth
}

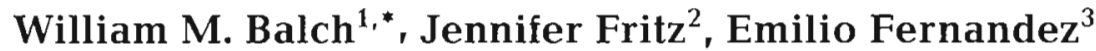 \\ ${ }^{1}$ Bigelow Laboratory for Ocean Sciences, PO Box 475, McKown Point, W. Boothbay Harbor, Maine 04575, USA \\ ${ }^{2}$ Rosenstiel School for Marine and Atmospheric Science, University of Miami, 4600 Rickenbacker Causeway, Miami, \\ Florida 33155, USA \\ ${ }^{3}$ Depto. Recursos Naturais e Medio Ambiente, Campus Lagoas-Marcosende, Universidade de Vigo, E-36200 Vigo, Spain
}

\begin{abstract}
Carbon fixation of Emiliania huxleyi was studied in light-limited, steady-state, continuous cultures. Six growth rates were examined ranging from 0.24 to $1.0 \mathrm{~d}^{-1}$ although the lowest may have been carbon-limited. Cell-specific and chlorophyll-specific rates of photosynthesis and calcification increased as a function of growth rate. The ratio of calcification to photosynthesis $(C / P)$ increased from about 0.2 to 0.7 as the growth rate increased (from 0.24 to $0.75 \mathrm{~d}^{-1}$ ), then the $C / P$ ratio decreased slightly as the growth rate approached washout at $1 \mathrm{~d}^{-1}$ Extrapolation of the regression data at low growth rates suggested that there should be zero calcification at a growth rate of about $0.1 \mathrm{~d}^{-1}$ Cells were also given a $30 \mathrm{~s}$ acidification/neutralization treatment to dissolve their coccoliths, and then carbon fixation was measured. Photosynthesis and calcification al all growth rates increased by about $0.1 \mathrm{pg} \mathrm{C}$ cell-1 $\mathrm{h}^{-1}$ following this treatment. Carbon fixation per unit chlorophyll a was predicted by multiplying the total carbon:chlorophyll a ratio by the respective culture dilution rate. These predictions were almost identical to ${ }^{14} \mathrm{C}$ measurements of carbon fixation per unit chlorophyll. Nevertheless, if only total carbon incorporation data are available for a coccolithophore population, accurate predictions of just photosynthesis or calcification will require the function (presented in this paper) which relates the $C / P$ ratio to growth rate. This function suggests a decoupling of photosynthesis from calcification as growth becomes progressively more light-limited.
\end{abstract}

KEY WORDS: Coccolithophores Calcification - Photosynthesis C Coccoliths · Growth rate

\section{INTRODUCTION}

Emiliania huxleyi (Lohm.) Hay \& Mohler is a ubiquitous coccolithophore, which produces elegantly sculptured calcium carbonate coccoliths, $2 \mu \mathrm{m}$ in diameter These calcite plates are shed as the cells grow, and they eventually sink to the sea floor, either freely or in zooplankton fecal pellets. It has long been recognized that coccoliths contribute a major portion of the calcite content of pelagic sediments (Lohmann 1908, Bramlette 1958) and the distribution of many coccolithophores in surface waters matches their sediment distribution (McIntyre \& Be 1967). Calcite carbon rep-

•E-mail: bbalch@bigelow.org resents a significant fraction of the total burial flux of carbon to the world's sediments (Milliman 1993, Westbroek et al. 1993). This flux of inorganic calcium carbonate is usually omitted in discussions of new production, yet the burial of calcite carbon is often equal to or greater than the burial of newly produced organic carbon, especially in oligotrophic and mesotrophic areas. Broecker \& Peng (1982) estimated that, globally, $1 \mathrm{~mol}$ of calcium carbonate is formed for every $4.5 \mathrm{~mol}$ of organic carbon but some $69 \%$ of the calcite sinks to the sea floor with $15 \%$ ultimately fixed into the geological archive. For organic carbon, Westbroek et al. (1993) estimated that an average of $15 \%$ reaches the sea floor, and only $0.075 \%$ is ultimately preserved in the sediments. The probability is about $6: 1$ that a biologically fixed atom of carbon, buried in the geological archive, 
will be in the form of calcite rather than organic carbon (Westbroek et al. 1993).

The rate of coccolith production is often, but not always, light-dependent. Calcification versus light curves are frequently hyperbolic, superimposed on a basal dark calcification rate (Paasche 1963, 1964, Balch et al. 1992, Nimer \& Merrett 1993). From the outset, the presence of calcification in light or darkness combined with light-dependent photosynthesis means that the ratio of the 2 processes must vary for coccolithophores, being mixed uniformly over the euphotic zone. The ratio of these 2 processes has been modeled as a function of depth; the calculations used photosynthesislight parameters and calcification-light parameters from batch culture experiments and assumed uniform mixing (Balch et al. 1992). The results suggested that the calcification/photosynthesis $(C / P)$ ratio should increase dramatically in the deeper reaches of the euphotic zone. Unfortunately, batch culture results often are difficult to interpret since nutrients are continually changing, and cell residues are continually accumulating in the flask.

The $C / P$ ratio has important consequences to our interpretation of the role of calcification in the Prymnesiophyceae. Sikes \& Wilbur (1982) examined the various roles that coccoliths might play, from increasing sinking rates, providing a cytoskeleton, maintenance of an inside-negative potential difference across the membrane, protection from herbivory, and cell volume regulation. One further hypothesis was that a complementary relationship between calcification and photosynthesis allows the cell to take up abundant bicarbonate supplies for calcification, with subsequent production of $\mathrm{CO}_{2}$ for photosynthesis. We will call this the calcification $/ \mathrm{CO}_{2}$ supply hypothesis. This mechanism would suggest that $C / P$ ratios should be approximately 1.0 if the 2 processes were tightly coupled.

Clearly, the idea of varying $C / P$ ratios is at odds with the calcification $/ \mathrm{CO}_{2}$ supply hypothesis. In this paper, Emiliania huxleyi was cultured continuously under light-limiting conditions (Eppley \& Dyer 1965), and the $C / P$ ratio was measured. Environmental. factors responsible for a given $C / P$ ratio were much more clearly defined under steady-state conditions than could be achieved in batch culture. The null hypothesis for these experiments was that the $C / P$ ratio would equal 1.0, no matter the growth rate, if the cells relied on $\mathrm{CO}_{2}$ from calcification as a carbon source for photosynthesis. Given expected variance in the $C / P$ ratio, then an important question concerned how the $C / P$ ratio would vary during the transition to low light conditions. E. huxleyi has been grown in steady-state chemostats only in 2 instances that we are aware of, Eppley et al. (1971; $N$-limited chemostats) and Pasche \& Brubak (1994; phosphorus-limited chemostats), and only the latter dealt with growth effects on calcification. There are no previously published reports of calcification in light-limited continuous cultures

\section{METHODS}

Continuous culture setup. The coccolithophore Emiliania huxleyi (clone 88E) was isolated from the Gulf of Maine (USA) in 1988. The original isolate was made axenic in November 1990, using the method of Droop (1967), but due to the multiple samplings of the reactor vessels, it occasionally was not possible to maintain axenic conditions throughout this experiment. Cells were grown in steady-state continuous culture as described in Fritz \& Balch (in press). This paper should be consulted for all culturing details. Briefly, the continuous culture vessels (New Brunswick Bioflo, New Brunswick, Canada) had a 1.5 l capacity and were supplied with modified $K$ media (Keller et al. 1987) via peristaltic pump. The seawater-based medium used less nitrate $(400 \mu \mathrm{M})$ and double phosphorus $(20 \mu \mathrm{M})$ but all other aspects of the medium were as described by Keller et al. (1987). Light was supplied by Sylvania GTE cool white fluorescent lamps with an irradiance of $75 \mu \mathrm{mol}$ quanta $\mathrm{m}^{-2} \mathrm{~s}^{-1}$. Even with the reduced nitrate concentrations, growth was ultimately limited by light as will be described in the 'Results' section (see also Fritz \& Balch in press). Average culture irradiance was inversely related to dilution rate, and varied between about 10 and $60 \mu \mathrm{mol}$ quanta $\mathrm{m}^{-2} \mathrm{~s}^{-1}$ (Fritz \& Balch in press). Temperature was maintained at $17 \pm 0.5^{\circ} \mathrm{C}$ during the experiments. Cell and coccolith counts were done using a PalmerMaloney counting chamber. Chlorophyll a (chl a) was determined using the fluorometric technique following overnight extraction in 90\% acetone (Yentsch \& Menzel 1963 as modified by Holm-Hansen et al. 1965). Estimates of total particulate carbon (TPC) and particulate inorganic carbon (PIC) were obtained according to Fernandez et al. (1993)

Calcification and photosynthesis measurements. The continuous culture reactor was sampled at 6 steady-state growth rates: $0.24,0.35,0.53,0.75,0.93$, and $0.99 \mathrm{~d}^{-1}$ (where steady-state was maintained for at least $5 \mathrm{~d}$ before sampling). For most experiments, each growth rate was sampled 3 times. The highest 2 growth rates were sampled only once. For each sampling, $135 \mathrm{ml}$ of steady-state culture were removed from the reactor and cell counts were immediately performed. An $85 \mathrm{ml}$ aliquot of this culture was injected. with $25 \mu \mathrm{l}$ of ${ }^{14} \mathrm{C}$ sodium bicarbonate $\left(74 \mathrm{MBq} \mathrm{ml}{ }^{i}=\right.$ $2 \mathrm{mCi} \mathrm{ml}^{-1} ; 2.07 \mathrm{GBq} \mathrm{mmol}^{-1}=56 \mathrm{mCi} \mathrm{mmol}^{-1}$ ) Three $0.1 \mathrm{ml}$ aliquots of the radioactive culture were immediately withdrawn and placed in 3 scintillation vials, 
each containing $0.1 \mathrm{ml}$ of phenethylamine, mixed thoroughly, and $7 \mathrm{ml}$ of Ecolume scintillation cocktail was added. Next, 3 subsamples of $21 \mathrm{ml}$ were withdrawn and placed in 3 acid-washed glass scintillation vials, and capped. A fourth aliquot of $20 \mathrm{ml}$ was added to a scintillation vial containing $1 \mathrm{ml}$ of concentrated (40\%) formaldehyde (final volume $=21 \mathrm{ml}$; final formaldehyde concentration $=1.9 \%$ ). All vials then were placed in a temperature-controlled incubator for 5 to $6 \mathrm{~h}$ in which the light level was $110 \mu \mathrm{mol}$ quanta $\mathrm{m}^{-2} \mathrm{~s}^{-1}$ (photosynthetically available radiation as measured by a Biospherical Instruments QSI-140B scalar irradiance sensor). At the termination of each experiment, two $10 \mathrm{ml}$ aliquots from each vial were withdrawn and filtered onto $25 \mathrm{~mm} 0.4 \mu \mathrm{m}$ Nuclepore filters using low vacuum (pressure reduction $<100 \mathrm{~mm} \mathrm{Hg}$ ). Filters were rinsed $4 \times$ using filtered seawater with the filter tower in place, and 1 'rim rinse' in which the tower was removed, and filtered seawater was carefully squirted around the rim of the filter with vacuum applied. One filter from each replicate was placed in a new scintillation vial along with $7 \mathrm{ml}$ of Ecolume scintillation cocktail. The other filter was placed in a desiccator with concentrated fuming $\mathrm{HCl}$ for 4 min, then placed in a clean scintillation vial with $7 \mathrm{ml}$ of Ecolume scintillation cocktail. We have determined in previous experiments (Balch et al. 1992) that no organic carbon is lost when non-calcifying coccolithophore strains are fumed over concentrated $\mathrm{HCl}$.

Radioactivity of the filters was determined using a TM Analytic scintillation counter calibrated using ${ }^{14} \mathrm{C}$ toluene standards. Quenching was corrected using the channels ratio method. Carbon uptake was calculated using the method of Parsons et al. (1984) with no isotope discrimination factor. Calcification was calculated using the difference between unfumed and fumed filter radioactivity, multiplied by the concentration of total dissolved inorganic carbon (TDIC; measured according to Parsons et al. 1984), divided by the total radioactivity per sample and the cell concentration. Photosynthesis was calculated using the same equation except the radioactivity of the fumed filters was substituted for the difference in radioactivity before and after fuming.

Acidification/neutralization experiments. For 10 experiments, the remaining culture aliquot was used for an experiment in which cells were denuded of coccoliths and then calcification and photosynthesis were measured. As one control, $5 \mathrm{ml}$ of untreated culture were removed prior to any treatment, preserved with $2 \mathrm{ml}$ glutaraldehyde, and examined later with the scanning electron microscope (SEM). We next added $0.6 \mathrm{ml} 1 \%$ glacial acetic acid to a $45 \mathrm{ml}$ subsample of culture to lower the $\mathrm{pH}$ to $5.2-5.5$, then stirred for $30 \mathrm{~s}$. An addition of $0.1 \mathrm{ml}$ of $1 \mathrm{M} \mathrm{Na}_{2} \mathrm{CO}_{3}$ brought the $\mathrm{pH}$ back up to 8.3 within the next $30 \mathrm{~s}$. Henceforth, these will be referred to as $\mathrm{A} / \mathrm{N}$-treated cells. A $5 \mathrm{ml}$ sample of the A/N-treated cells was immediately preserved with $2 \mathrm{ml}$ gluteraldehyde for subsequent examination with the SEM to verify coccolith dissolution. Another 5 ml sample was placed in an acid-cleaned scintillation vial and was examined after the experiment with the SEM to observe new coccolith formation. $370 \mathrm{KBq}$ $(10 \mu \mathrm{Ci}){ }^{14} \mathrm{C}$ bicarbonate was added to the remaining $35 \mathrm{ml}$ of $\mathrm{A} / \mathrm{N}$-treated cells and three $11 \mathrm{ml}$ aliquots were placed in scintillation vials. A $5 \mathrm{ml}$ formalinkilled sample also was prepared as a blank. All vials were capped and placed in the temperature-controlled incubator for 5 to $6 \mathrm{~h}$ at an irradiance of $110 \mu \mathrm{mol}$ quanta $\mathrm{m}^{-2} \mathrm{~s}^{-1}$. The ${ }^{14} \mathrm{C}$-inoculated vials were filtered as described above to determine calcification and photosynthesis rates. The only change was that the calculation of photosynthesis and calcification included the TDIC of both seawater plus the TDIC added during the neutralization step. We assumed that the carbonate equilibrium was slow enough that negligible $\mathrm{CO}_{2}$ gas was lost from the media during the $30 \mathrm{~s}$ acidification step (Stumm \& Morgan 1981).

\section{RESULTS}

\section{Growth limitation}

Light limitation was determined according to the relationships described by Eppley \& Dyer (1965). Basically, if light attenuation occurs according to the BeerLambert law, then:

$$
I=I_{0} \mathrm{e}^{-\left(N c_{c e l i} d\right)}
$$

where $I_{0}$ is the incident photon flux, $I$ is the flux at distance $d, c_{c e l l}$ is the cell-specific attenuation coefficient $\left(\mathrm{m}^{2}\right.$ cell $\left.{ }^{-1}\right)$, and $N$ is the concentration of cells (cells $\mathrm{m}^{-3}$ ). Note that for purposes of derivation, $c_{\text {celi }}$ includes attenuation due to cellular inorganic and organic matter, but the ratio of carbon in these 2 cellular pools remained fairly constant (about 0.3 to 0.4 ) (Fernandez et al. in press). Therefore, for simplicity, we considered the total cell-specific attenuation, $C_{\text {cell }}$, to be constant. In the culture vessel, $d$ was also constant, so we designated the product of $d$ and $c_{\text {cell }}$ to be a constant, $k$ (units $\mathrm{m}^{3}$ cell ${ }^{-1}$ ). Eq. (1) was then rearranged:

$$
k N=\ln \left(I_{0} / I\right)
$$

and converting to base 10 logarithms:

$$
N=2.3 / k\left[\log \left(I_{0} / I\right)\right]
$$

A plot of $\log I_{0} / I$ versus $N$ should yield a straight line with slope $2.3 / k$, if there was a constant relation between light level and cell abundance. Moreover, the 
rate of cell production in continuous cultures, $P_{\text {cell }}$ (cells $\mathrm{m}^{-3} \mathrm{~d}^{-1}$ ) was calculated as:

$$
P_{\text {cell }}=\mu N
$$

where $\mu$ was the steady-state division rate (Ketchum \& Redfield 1938, Ketchum et al. 1949). Eppley \& Dyer (1965) also showed that, in light-limited continuous cultures, the concentration of cells was inversely related to growth rate, $\mu$

$$
N=h\left(\mu_{\max }-\mu\right)
$$

where $\mu_{\max }$ was the maximal growth rate, and $h$ was another constant [(cells $\left.\mathrm{m}^{-3}\right) \times d$ ]. In light-limited continuous cultures, Eqs. (3) \& (5) can be combined to relate growth to irradiance:

$$
\left(\mu_{\max }-\mu\right)=(2.3 / k h) \log \left(I_{0} / I\right)
$$
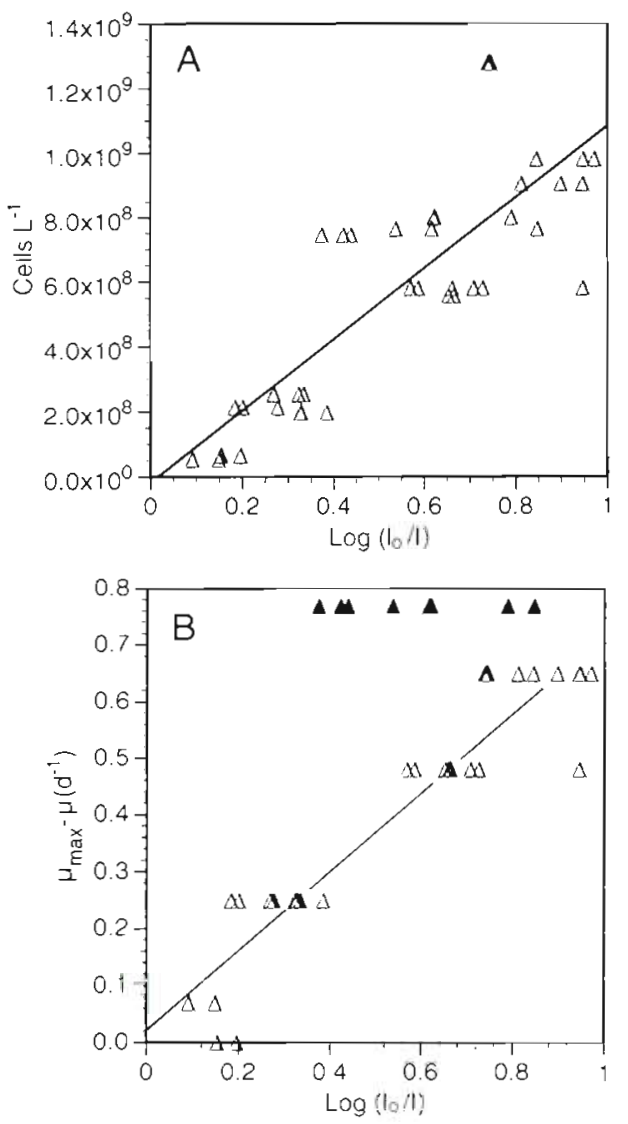

Fig. 1. Confirmation of light limitation of continuous cultures (A) Plot of cell concentration (per liter) versus $\log \left(I_{0} / I\right)$ for all continuous culture experiments. Least-squares linear fit with standard error terms (in square brackets) was: $N\left[2.064 \times 10^{8}\right]$ $=1.101 \times 10^{9}\left[1.267 \times 10^{8}\right] \log \left(I_{0} / I\right)-1.751 \times 10^{7}\left[7.787 \times 10^{7}\right]$ $\left(r^{2}=0.67 ; n=40 ; p<0.001\right.$, Type 1 error $)$. (B) Plot of $\left(\mu_{\max }-\mu\right)$ versus $\log \left(l_{0} / I\right)$ for contınuous cultures. Least-squares linear fit to all data $(\Delta)$ except the lowest growth rate $\left(0.23 \mathrm{~d}^{-1} ; \mathbf{A}\right)$ $\left(\mu_{\mathrm{max}}-\mu\right)\{0.075]=0.701[0.048] \log \left(I_{0} / I\right)+0.020[0.030]\left(\mathrm{r}^{2}=\right.$ $0.88 ; \mathrm{n}=31 ; \mathrm{p}<0.001$. Type 1 error) such that a plot of $\left(\mu_{\max }-\mu\right)$ versus $\log \left(I_{0} / I\right)$ should have given a straight line with a constant slope of $2.3 / \mathrm{kh}$.

A plot of cell concentration $(N)$ versus $\log \left(I_{0} / I\right)$ had a least-squares fit that accounted for $67 \%$ of the variance of $N$ (Fig. 1A). Henceforth, all statistical fits are given in the figure legends along with the standard errors of the fitted parameters. Note, the intercept was not significantly different from zero. Moreover, a plot of $\left(\mu_{\text {miax }}\right.$ - $\mu$ ) versus $\log \left(I_{0} / I\right)$ was also reasonably fit with a straight line (Fig, 1B) and the intercept was not significantly different from zero. The straight line fit suggested a relatively constant relation between cell abundance and light level for all growth rates except $0.24 \mathrm{~d}^{-1}$ The data for this growth rate (largest $\mu_{\max }-\mu$ ) clearly did not fit the trend defined by the rest of the data, suggesting that growth was not limited by light in these samples. Excluding the lowest growth rate, $\log \left(I_{0} / I\right)$ accounted for $88 \%$ rather than $53 \%$ of the variance in $\left(\mu_{\max }-\mu\right)$. The reasonable fit of the data to Eqs. (3) and (6) suggests that the cultures were indeed light-limited for all but the lowest growth rate.

In terms of other potential limitation, it should be noted that nitrate and phosphate were always detectable in the medium and dissolved inorganic carbon levels were close to seawater values at all growth rates except 2. The pH, TDIC and alkalinity data are summarized in Table 1 Note, the mean alkalinity for the $0.93 \mathrm{~d}^{-1}$ sample appeared to be anomalously low (see also Fig. 1B of Fritz \& Balch in press). Normally, this would have been expected to result from high coccolith production rates; in fact, coccolith concentrations were low at this growth rate (see Fritz \& Balch in press, their Fig. 2A). Analytical error may have been responsible for this low alkalinity value but the precision showed no indication that the data were suspect. While this alkalinity data point should be interpreted cautiously, there is insufficient evidence to eliminate it from our data set and the variance in alkalinity at this

Table 1. Variability of $\mathrm{pH}$, total alkalinity (TAlk) and $\Sigma \mathrm{CO}_{2}$ as a function of growth rate in the continuous cultures

\begin{tabular}{|lccc|}
\hline $\begin{array}{l}\mu \\
\left(\mathrm{d}^{-1}\right)\end{array}$ & $\mathrm{pH}$ & $\begin{array}{c}\text { TAlk } \\
\left(\mathrm{meq}^{-1}\right)\end{array}$ & $\begin{array}{c}\Sigma \mathrm{CO}_{2} \\
(\mathrm{mM})\end{array}$ \\
\hline 0.24 & 8.56 & 1.64 & 1.20 \\
0.24 & 8.73 & 0.94 & 0.62 \\
0.24 & 8.74 & 1.47 & 1.06 \\
0.35 & 8.30 & 1.89 & 1.63 \\
0.35 & 8.40 & 2.04 & 1.71 \\
0.35 & 8.54 & 2.22 & 1.82 \\
0.53 & 8.34 & 2.23 & 1.89 \\
0.75 & 8.03 & 2.12 & 1.99 \\
0.75 & 8.05 & 2.10 & 1.93 \\
0.75 & 8.06 & 1.67 & 1.52 \\
0.93 & 8.08 & 1.28 & 1.15 \\
0.99 & 7.93 & 2.32 & 2.21 \\
\hline
\end{tabular}


growth rate remains unexplained. At the lowest growth rate $\left(0.23 \mathrm{~d}^{-1}\right)$, the TDIC levels were the lowest of the study (between 0.62 and $1.2 \mathrm{mM}$ ), while at $0.93 \mathrm{~d}^{-1}$, the TDIC was $1.15 \mathrm{mM}$ (Table 1), still about $65 \%$ of typical seawater concentrations and likely above saturation levels for Emiliania huxleyi at low light levels (Nimer \& Merrett 1993). The TDIC data, taken together with the results of Fig. 1, suggest that growth may have been carbon limited at the $0.23 \mathrm{~d}^{-1}$ growth rate.

\section{Calcification and photosynthesis as a function of growth}

Photosynthesis ( $P$; pg $C$ cell $^{-1} \mathrm{~h}^{-1}$ ) and calcification ( $C$; same units) were measured at 1 irradiance, $110 \mu \mathrm{mol}$ quanta $\mathrm{m}^{-2} \mathrm{~s}^{-1}$. The carbon fixation rates described below were representative of the rates within the continuous culture reactor because (1) total carbon fixation rates were almost identical to the product of the growth rate and standing stock of total particulate carbon within the reactor (see 'Discussion'), and (2) the ratios of the standing stocks of organic and inorganic carbon were similar to the ratio of photosynthesis and calcification (see chemical composition data for the same experiment; Table 2 of Fernandez et al. in press). Had the irradiance levels been perturbed significantly between reactor and incubation vial, neither of the above would have been true.

The $P$ and $C$ data (Fig. 2A) were fitted by straight lines with intercepts that were not significantly different from zero. The data from the $0.53 \mathrm{~d}^{-1}$ cells were higher than predicted from the least-squares fit line. As discussed in Fritz \& Balch (in press) the chl a per cell generally decreased with increasing growth rate with the exception of the cells at $0.53 \mathrm{~d}^{-1}$. When the photosynthesis and calcification rates were normalized to chl $a\left(P_{\mathrm{b}}\right.$ and $C_{\mathrm{b}}$ respectively; $\mathrm{g} \mathrm{C} \mathrm{g} \mathrm{chl} \mathrm{a}^{-1}$ $\left.\mathrm{h}^{-1}\right)$, it can be seen that the results still showed the same trend, but there was less scatter in the data (Fig. 2B).

Photosynthesis always exceeded calcification. When rates were normalized by the cell concentration, photosynthesis was greater than calcification by about 0.1 to $0.2 \mathrm{pg} \mathrm{C}$ cell ${ }^{-1} \mathrm{~h}^{-1}$, regardless of growth rate (Fig. 3A). When the data were normalized to chlorophyll, $P_{\mathrm{b}}$ exceeded $C_{\mathrm{b}}$ by about 0.3 to $1.0 \mathrm{~g} \mathrm{C} \mathrm{g}$ chl $a^{-1} \mathrm{~h}^{-1}$.

The relationship between the calcification:photosynthesis ratio $(C / P)$ versus growth rate was curvilinear (Fig. 4A). At the lowest growth rates, the average $C / P$ was about 0.2 . The peak $C / P$ average was about 0.7 at a growth rate of $0.75 \mathrm{~d}^{-1}$, and then as cells approached
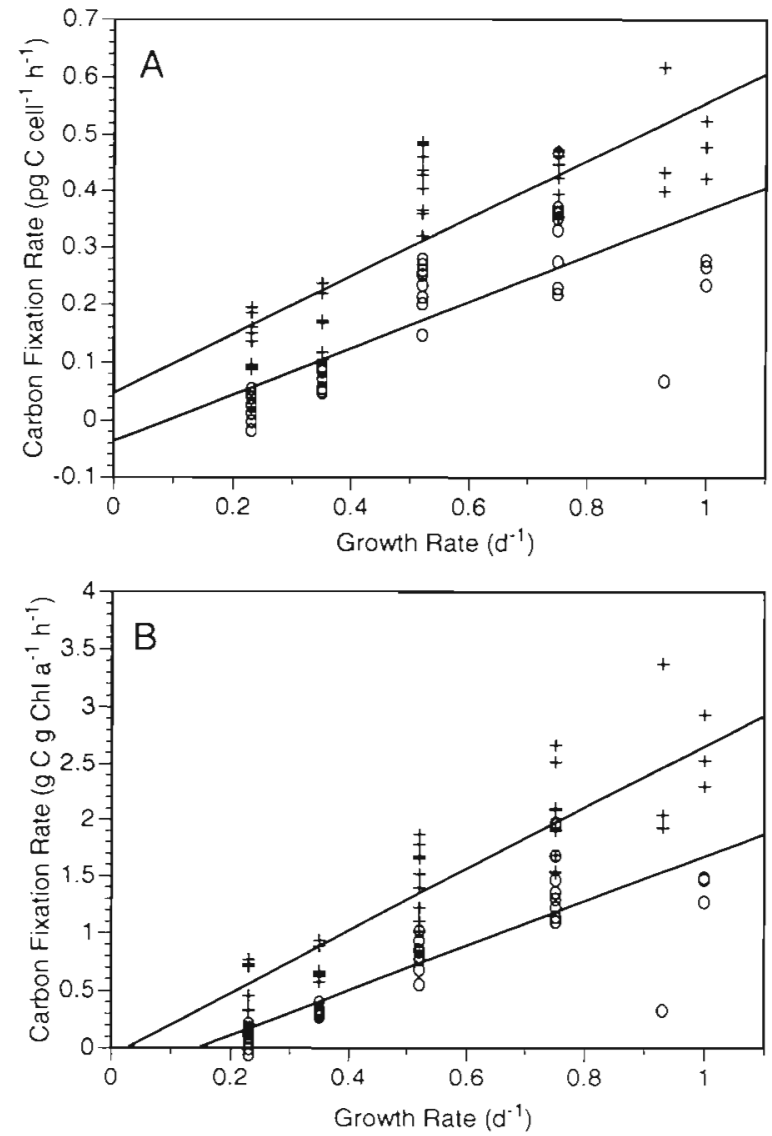

Fig. 2. (A) Photosynthesis per cell and calcification per cell versus growth rate at 6 steady-state growth rates. Leastsquares linear fits with standard error terms (in square brackets) were: $P[0.081]=0.509[0.050] \mu+0.047[0.029],\left(\mathrm{r}^{2}=0.73\right.$ $\mathrm{n}=42 ; \mathrm{p}<0.001$, Type 1 error) and $C[0.084]=0.402[0.055] \mu-$ $0.036[0.031],\left(\mathrm{r}^{2}=0.59 ; \mathrm{n}=40 ; \mathrm{p}<0.001\right.$, Type 1 error $)$. (B) Photosynthesis and calcification normalized to chl a versus growth rate at 6 steady-state growth rates. Least-squares linear fits with standard error terms (in square brackets) were: $P_{\mathrm{b}}[0.336]=2.72[0.207] \mu-0.068[0.123]\left(\mathrm{r}^{2}=0.82 ; \mathrm{n}=41 ; \mathrm{p}<\right.$ 0.001 , Type 1 error) and $C_{b}[0.315]=1.95[0.207] \mu-$ $0.278[0.119]\left(\mathrm{r}^{2}=0.71 ; \mathrm{n}=39 ; \mathrm{p}<0.001\right.$, Type 1 error $) .(+)$ Photosynthesis; (o) calcification

washout, the $C / P$ ratio decreased slightly to 0.6 . Fig. 4B shows the same data but as percent calcification $(\% C)$ versus growth rate.

Following the acidification/neutralization treatment, the calcification $\left(C_{\mathrm{A} / \mathrm{N}}\right)$ and photosynthesis $\left(P_{\mathrm{A} / \mathrm{N}}\right)$ rates were more similar. On average, calcification was $66 \%$ of photosynthesis (Fig. 5). It can seen that following the $\mathrm{A} / \mathrm{N}$ treatment, the calcification and photosynthesis rates increased about $0.1 \mathrm{pg} \mathrm{C} \mathrm{Cell}^{-1} \mathrm{~h}^{-1}$ (Fig. 6). The ratio of calcification to photosynthesis $(C / P)$ ranged from about 0 to 1 over all growth rates prior to $A / N$ treatment but following $\mathrm{A} / \mathrm{N}$, most of the $C / P$ ratios were between 0.5 and 1 (Fig. 7). 

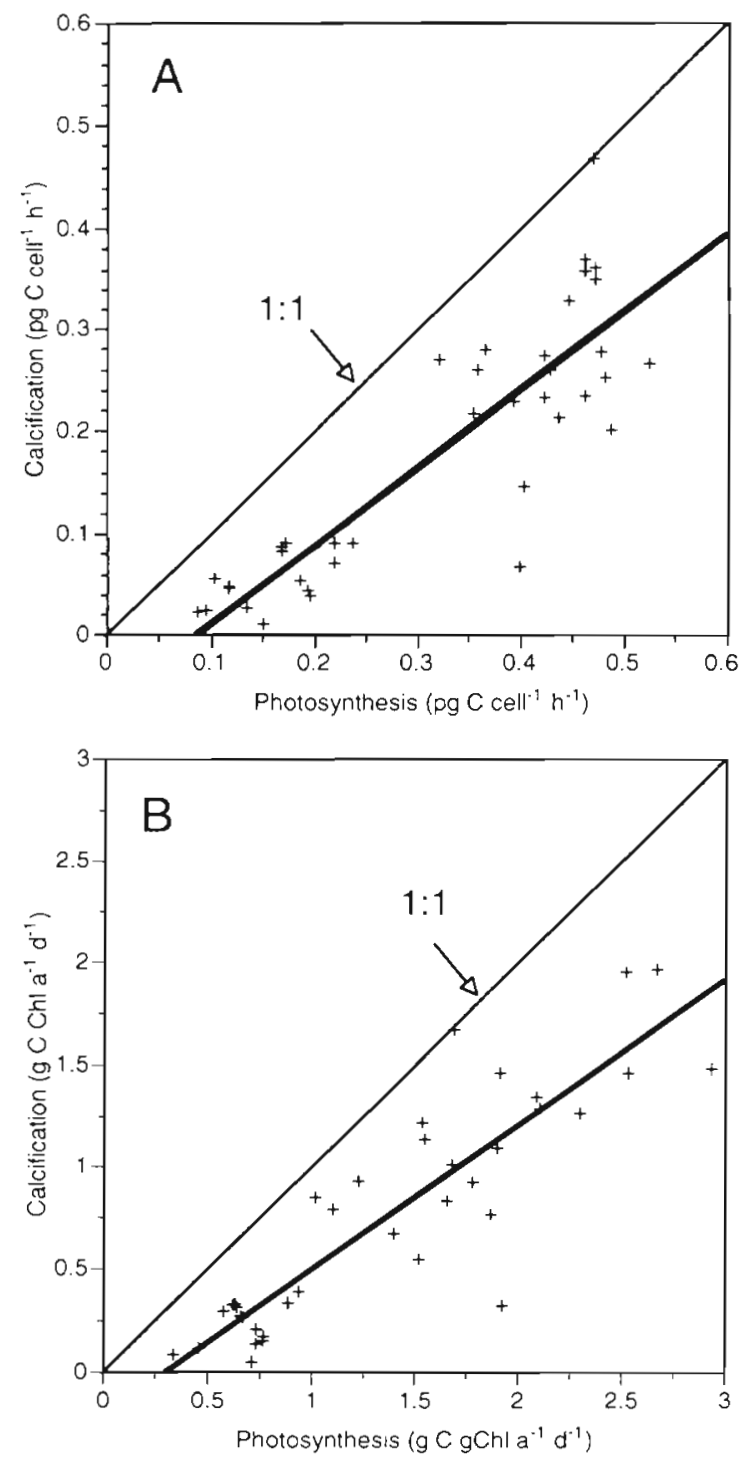

Fig. 3. Calcification rate versus photosynthesis rates for all samples. 1:1 line is shown for reference. (A) Rates normalized to cell number. Least-squares linear fit with standard error terms (in square brackets) was: $C[0.063]=0.765[0.068] P-$ $0.066[0.023]\left(r^{2}=0.77 ; n=40 ; p<0.001\right.$, Type 1 error $)$. (B) Rates normalized to chl a concentration. Least-squares linear fit with standard error terms (in square brackets) was: $C_{b}[0.270]=0.709[0.061) F_{n}-0.211[0.092]\left(r^{2}=0.7 \partial_{;} n=39 ;\right.$ $p<0.001$, Type 1 error)

\section{DISCUSSION}

\section{Changing $C / P$ ratio with growth}

The growth rate of Emiliania huxleyi (clone $88 \mathrm{E}$ ) varied from 0.23 to $1.0 \mathrm{~d}^{-1}$ in this experiment and the $C / P$ ratio varied from 0 to 1 . Of particular interest, from a physiological and ecological perspective, are the factors regulating the ratio of calcification to photosynthe-
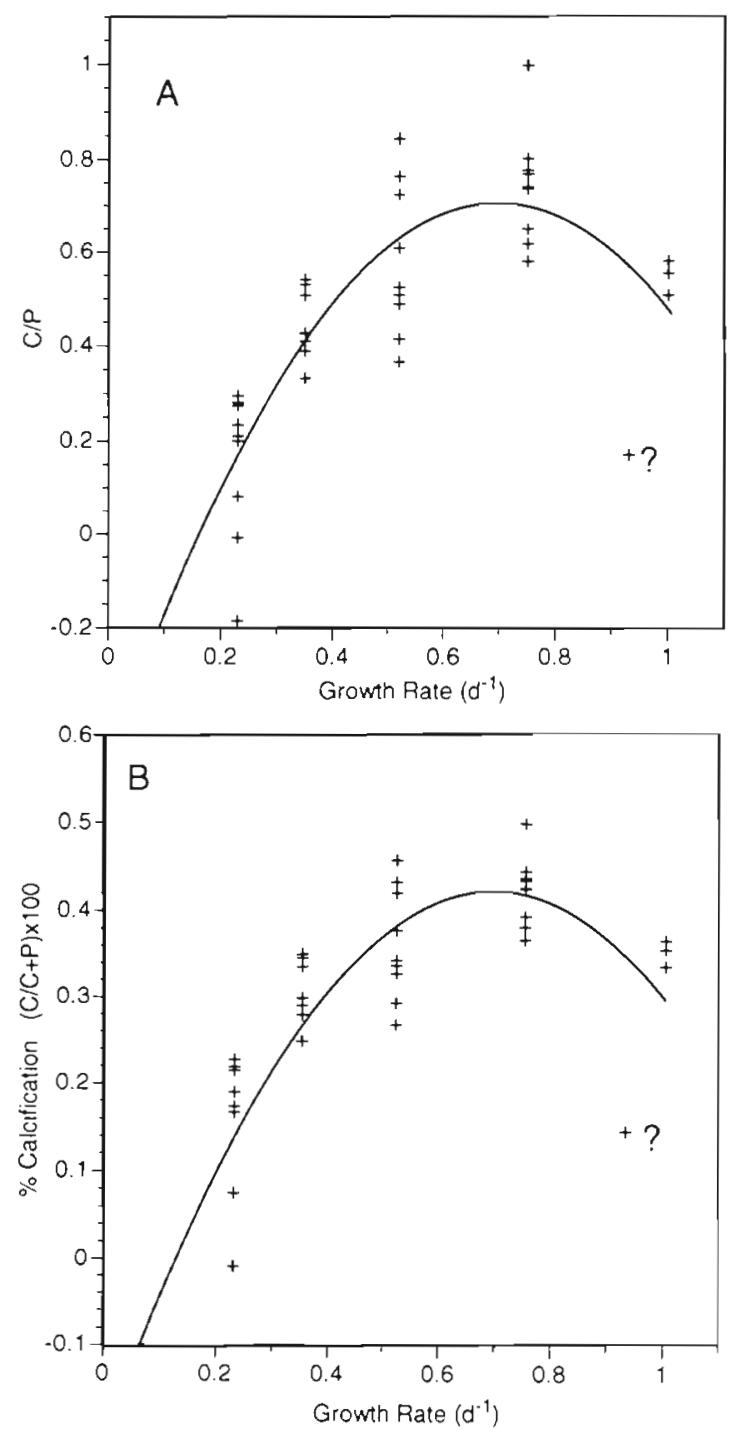

Fig. 4. (A) Ratio of calcification to photosynthesis as a function of steady-state growth rate. Line represents a least-squares polynomial fit to all of the data. Least-squares linear fit with standard error terms (in square brackets) was: $C / P[0.149]=$ $-2.48[0.437] \mu^{2}+3.44[0.512] \mu-0.49[0.130]\left(\mathrm{r}^{2}=0.65 ; \mathrm{n}=39\right.$; $p<0.001$. Type 1 error). (B) Percent of total carbon fixation contributed by calcification $(\% \mathrm{C})$ versus growth rate. Leastsquares fit to these data is: \% C $[0.092\}=-1.33[0.269] \mu^{2}+$ $1.84[0.316] \mu-0.21[0.080]\left(r^{2}=0.58 ; n=39 ; \mathrm{p}<0.001\right.$, Type 1 error)

sis. A C/P ratio approaching zero mainly was due to calcification slowing at low growth rates; the $x$ intercepts of Fig. $2 A$ and $B$ suggested that calcification would stop at a growth rate of about $0.1 \mathrm{~d}^{-1}$ (Fig. 2; Eqs. 8 \& 10). Paasche (1964) wrote extensively on the $C / P$ ratio for various $E$. huxleyi clones and observed $C / P$ ratios ranging from average values of 0.67 to 1.39 . This was not expected given the commonly perceived stoichiometry for calcification (Paasche 1964, Sikes et 


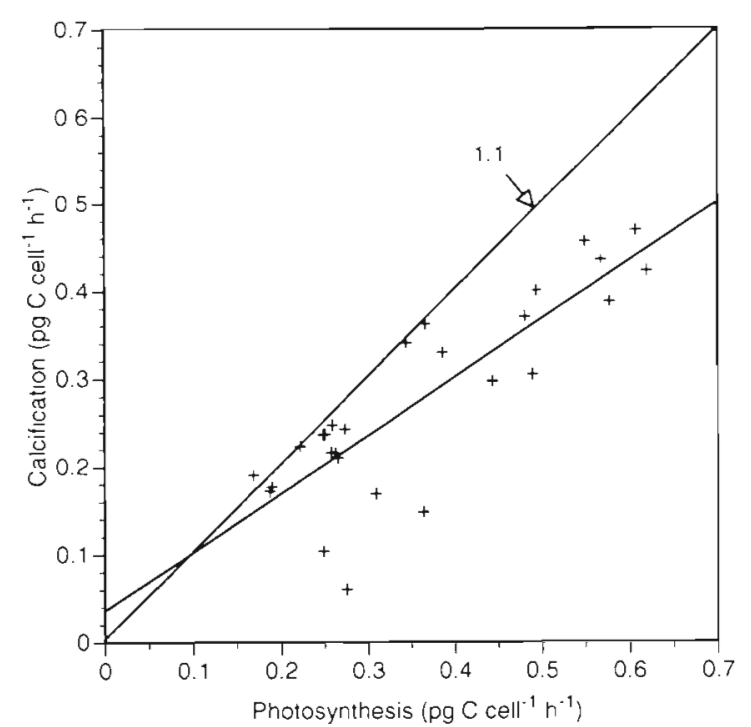

Fig. 5. Calcification versus photosynthesis after $\mathrm{A} / \mathrm{N}$ treatment. Least-squares linear fit with standard error terms (in square brackets) was: $C_{\mathrm{A} / \mathrm{N}}[0.060]=0.664[0.084] P_{\mathrm{A} / \mathrm{N}}+3.65 \times$ $10^{-2}[0.032]\left(r^{2}=0.72 ; n=27 ; p<0.001\right.$, Type 1 error $)$. A $1: 1$ line is shown for reference

al. 1980, Nimer \& Merrett 1992, 1993, Dong et al. 1993, Paasche \& Brubak 1994):

$$
\mathrm{Ca}^{++}+2 \mathrm{HCO}_{3}^{-} \rightarrow \mathrm{CaCO}_{3}+\mathrm{CO}_{2}+\mathrm{H}_{2} \mathrm{O}
$$

Previous results suggest that $E$. huxleyi uses bicarbonate as the substrate for calcium carbonate, and

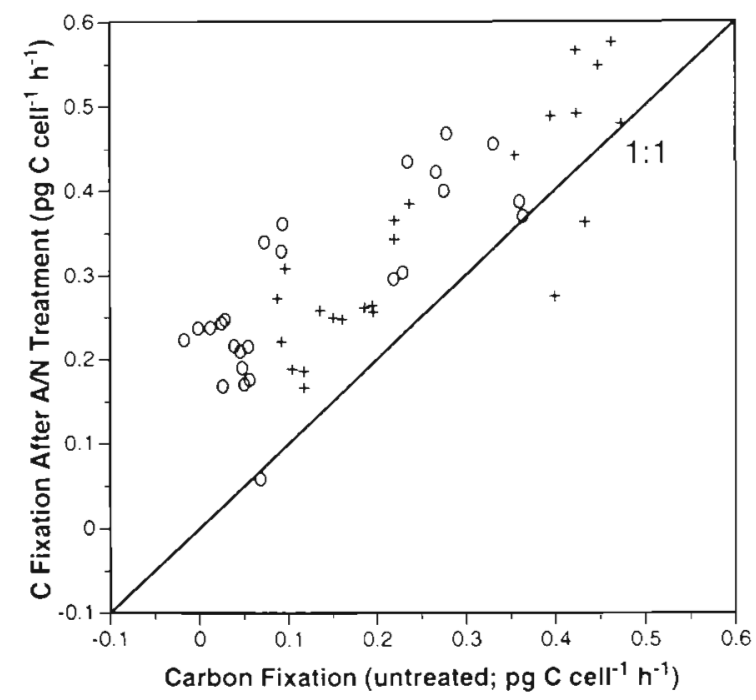

Fig. 6. Carbon fixation after $\mathrm{A} / \mathrm{N}$ treatment versus carbon fixation by untreated cells. (+) Photosynthesis; (O) calcification. A 1:1 line is shown for reference. In all but 2 instances $(0.35$ $\mathrm{d}^{-1}$ and $0.53 \mathrm{~d}^{-1}$, photosynthesis and calcification rates increased by about $1 \mathrm{pg} \mathrm{C}$ cell ${ }^{-1} \mathrm{~h}^{-1}$ following $\mathrm{A} / \mathrm{N}$ treatment. See text for details

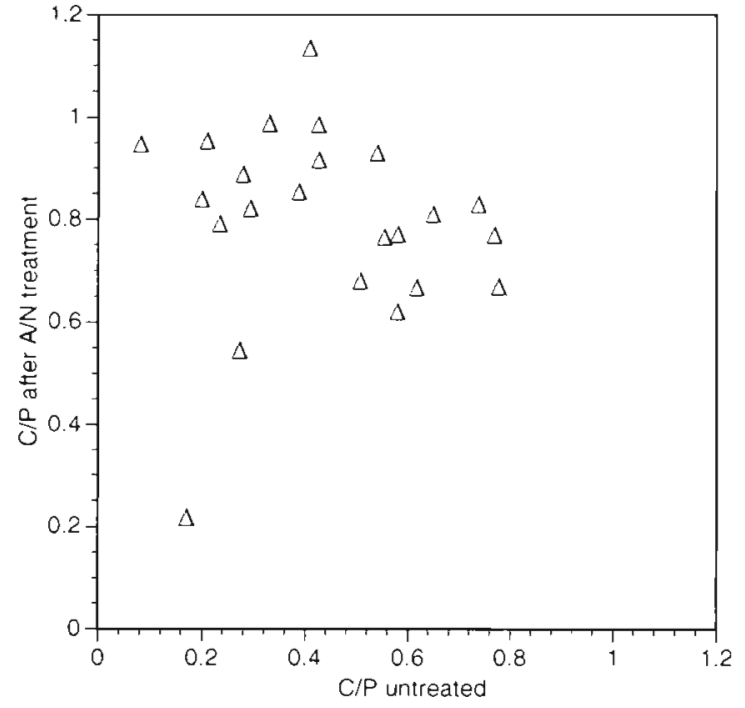

Fig. 7. Ratio of calcification to photosynthesis after $\mathrm{A} / \mathrm{N}$ treatment versus the same ratio for untreated cells. C/P ratio of untreated cells varied from 0 to 0.75 , the ratio following $\mathrm{A} / \mathrm{N}$ treatment generally was between 0.5 and 1

the resulting $\mathrm{CO}_{2}$ is used in photosynthesis; this ideally would give a 1:1 ratio between calcification and photosynthesis. Paasche (1964) pointed out that deviations of the $C / P$ ratio from 1 may be partially due to experimental error in the photosynthesis measurement. That is, he estimated the error in his photosynthesis numbers to be a total of $22 \%: 12 \%$ for respiration, $5 \%$ for excretion of dissolved organic carbon (plus accounting for an initial lag in photosynthesis), and $5 \%$ for isotope discrimination. Paasche $(1964$; his Table 5) did not need to make corrections for his calcification rates, so he divided the $C / P$ ratios by 1.22 . This would change the range of his average $C / P$ values to a lower limit of $0.55(0.67 / 1.22)$ and an upper limit of $1.14(1.39 / 1.22)$ but some of these values were still significantly different from the expected value of 1.0 .

The $C / P$ ratios given in Figs. $4 \& 7$ of this paper were all less than 1 ; dividing them by 1.22 to account for the types of measurement error described by Paasche (1964) would drive them even further from the hypothesized value of unity. In order for our $C / P$ data to be consistent with Eq. (7), then the experimental error would have had to change with growth rate. Moreover, the error would have been enormous for cells growing at $0.23 \mathrm{~d}^{-1}$; calcification would have to have been underestimated (or photosynthesis overestimated) by a factor of $>5$ to achieve our observed results. Given that the $\mathrm{pH}$ of the bulk media never went below 7.8 , then coccolith dissolution would not have caused calcification to be underestimated. 
Regardless of whether the above error terms should be applied to our data, it is important to note that $C / P$ ratios also vary in batch culture experiments. Balch et al. (1992) observed C/P ratios of about 2 for Emiliania huxleyi (88E) in early log growth which decreased to $<1$ in stationary phase. While the magnitude of the $C / P$ ratios was different in Balch et al. (1992) than in this work, the trends were similar. The faster the growth rate, the greater the $C / P$ ratio. We have 2 conclusions from these data and previous results: (1) part of the variability in the $C / P$ ratio may have been due to the abovementioned error terms, but this error was small relative to the trends of the data; and (2) calcification and photosynthesis were increasingly decoupled as growth slowed under light limitation. That is, $\mathrm{CO}_{2}$ generated during calcite precipitation was not the only carbon source for photosynthesis at progressively lower growth rates.

\section{Carbon saturation at low light levels}

Even though carbon speciation would have changed with $\mathrm{pH}$, this was not enough to cause carbon limitation except at possibly the lowest growth rate examined here. Earlier results by Paasche (1964; his Fig. 17) demonstrated that carbon limitation occurred at TDIC concentrations $>2 \mathrm{mM}$ at a pH of 7.5 to 8.0 , higher than our TDIC concentrations. He also showed (in his Fig. 28) that the uptake of bicarbonate was saturated at concentrations of about $2 \mathrm{mM}$; again, higher than most of the TDIC concentrations in our cultures (Table 1). Recent results of Nimer \& Merrett (1993) suggest an interesting feature of the kinetics, however. Their results match Paasche's observations using light-saturated Emiliania huxleyi strain $88 \mathrm{E}$ but at a sub-saturating irradiance of $50 \mu \mathrm{mol}$ quanta $\mathrm{m}^{-2} \mathrm{~s}^{-1}$, similar to the irradiance levels in our light-limited cultures; they demonstrated that calcification and photosynthesis saturate at a TDIC concentration of only $0.5 \mathrm{mM}$, lower than the TDIC levels seen in all of our experiments. The implication is that even though our culture TDIC concentrations were sometimes below typical seawater values, the low light conditions meant that cells were carbon-saturated at all but the lowest growth rate, and cell growth was still fundamentally light-limited.

\section{$\mathrm{CO}_{2}$ versus $\mathrm{HCO}_{3}{ }^{-}$as a carbon source for photosynthesis and calcification}

There is considerable history in the debate about $\mathrm{CO}_{2}$ versus $\mathrm{HCO}_{3}^{-}$as a carbon source in calcification and photosynthesis of Emiliania huxleyi. Lewin (1962) hypothesized that photosynthesis and calcification re- lied on a common carbon source, bicarbonate. Paasche (1964; p. 43) suggested that this species could use bicarbonate and molecular $\mathrm{CO}_{2}$ for photosynthesis but naked cells had lower maximal photosynthesis rates, which he attributed to a reduced ability to precipitate calcite. Steemann Nielsen (1966), using Paasche's data, concluded that naked strains of E. huxleyi were photosynthesizing using $\mathrm{CO}_{2}$, not bicarbonate, as a carbon source. However, Paasche \& Klaveness (1970) presented new data suggesting no difference between naked and plated cells in their use of bicarbonate as a carbon source, contrary to Steemann Nielsen's earlier contention. Sikes et al. (1980) concluded that noncalcifying $E$. huxleyi cells used only $\mathrm{CO}_{2}$, but they could not completely eliminate bicarbonate as a carbon source in photosynthesis; plated $E$. huxleyi cells appeared to use both $\mathrm{CO}_{2}$ and $\mathrm{HCO}_{3}{ }^{-}$. More recently, Nimer \& Merrett (1993) and Dong et al. (1993) have published results supporting the interpretation of Sikes et al. (1980) in which $\mathrm{CO}_{2}$ and $\mathrm{HCO}_{3}{ }^{-}$both act as carbon sources for plating E. huxleyi strains.

Our results would also support there being at least 2 inorganic carbon sources for photosynthesis and that a decoupling is occurring between photosynthesis and calcification as a function of growth rate. At low growth rates (and irradiance), $\mathrm{CO}_{2}$ for photosynthesis was not coming from calcification but from either (1) $\mathrm{CO}_{2}$ diffusion into cells or (2) low levels of carbonic anhydrase converting $\mathrm{HCO}_{3}{ }^{-}$to $\mathrm{CO}_{2}$; this would allow $C / P$ ratios to be low. Such an interpretation is supported by the work of Quiroga \& Gonzalez (1993) in which carbonic anhydrase was found at high specific activity in the chloroplasts of a coccolithophorid (Bigelow Laboratory clone CCMP 299); thus, cells may be able to use $\mathrm{HCO}_{3}{ }^{-}$directly as a carbon source without relying on calcification as a source of $\mathrm{CO}_{2}$. This was also suggested by Steemann Nielsen (1966). Our data are most consistent with the hypothesis that at higher light-limited growth rates, photosynthetic carbon fixation relied more on the $\mathrm{CO}_{2}$ generated from calcification, and the $C / P$ ratios approached 1 In summary, maximum coupling between calcification and photosynthesis occurred at higher light levels and growth rates (Fig. 4) which is when Eq. (7) came the closest to describing our data.

\section{$\mathrm{A} / \mathrm{N}$ treatment effects}

Rapid dissolution of coccoliths (and re-neutralization) caused the calcification and photosynthesis rates to increase as shown in Figs. $5 \& 6$, in agreement with Linschooten et al. (1991). Using a value of $0.2 \mathrm{pg} \mathrm{C}$ per coccolith, the average coccolith production rate for untreated cells would have ranged from 0 to $1.75 \mathrm{coc}$ - 
coliths cell ${ }^{-1} \mathrm{~h}^{-1}$ as growth rate increased. The data for A/N-treated cells would have had a range from 0.3 to 3 coccoliths cell ${ }^{-1} \mathrm{~h}^{-1}$. Our experiments did not last long enough to determine whether coccolith production slowed following production of a complete coccosphere as observed by Linschooten et al. (1991). The increase in calcification after $\mathrm{A} / \mathrm{N}$ treatment should not have been due to higher TDIC levels (from the neutralization step) since the cells were already carbon saturated (due to the low light levels; Nimer \& Merrett 1993). As for the increase in photosynthesis following A/N treatment, this is contrary to previous results of Paasche \& Klaveness (1970), in which naked and plated cells showed the same photosynthesis-light curves. The cellular mechanism to stimulate photosynthesis after coccolith dissolution remains unknown but if calcification was stimulated then photosynthesis might have also increased according to the stoichiometry in Eq. (7). It was also worthy of note that the C/P ratios of $\mathrm{A} / \mathrm{N}$ treated cells were higher than untreated cells, most between 0.6 and 1.0 (Fig 7 ).

\section{Modeling calcification, photosynthesis and total carbon assimilation}

In continuous cultures, the biomass multiplied by the growth rate should approximate the production rate (Eq. 4). One of the goals of our research is the prediction of calcification and photosynthesis rates, so we checked whether the predicted production of calcite and organic matter matched the rate measured with ${ }^{14} \mathrm{C}$. Fig. 8 shows the predicted organic carbon fixation rates for all experiments, compared with the measured
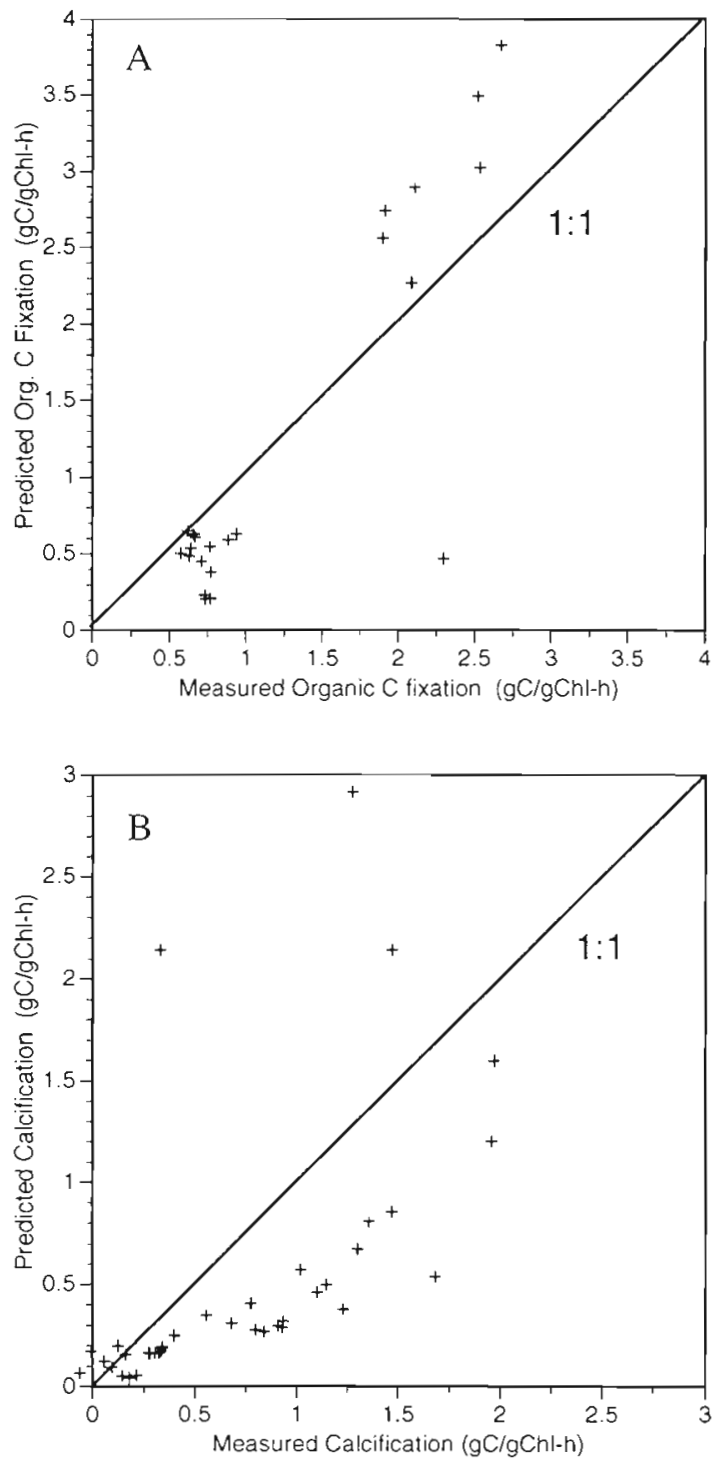

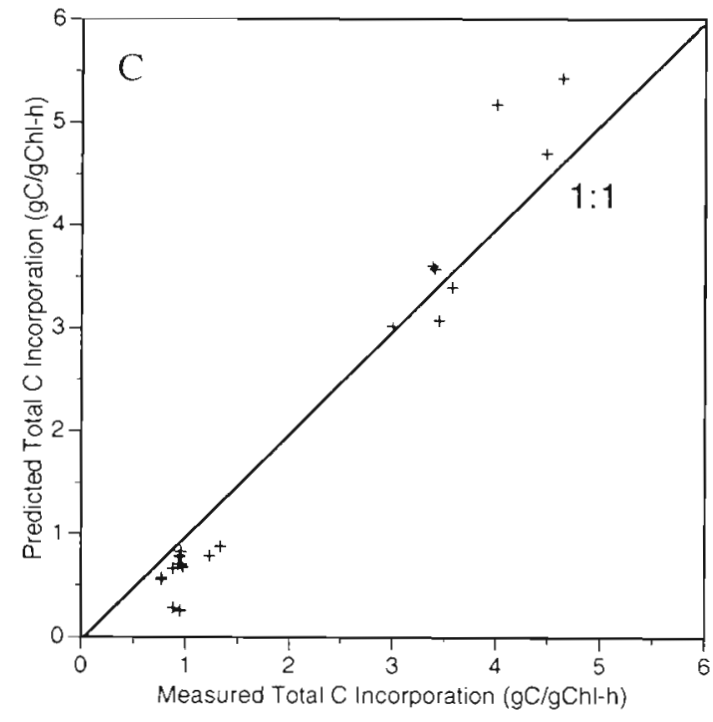

Fig. 8. Predicted (Pred) carbon fixation ( $\mathrm{g} \mathrm{C} \mathrm{g} \mathrm{chl} \mathrm{a}^{-1} \mathrm{~h}^{-1}$ ) plotted against measured (Meas) organic $\mathrm{C}$ fixation using ${ }^{14} \mathrm{C}$ incubations. Predicted values calculated by multiplying growth rate $\left(\mathrm{d}^{-1}\right)$ by the carbon/chl a ratio. A 1:1 line is shown for reference. Results shown for carbon fixation into $(A)$ organic matter (Pred $P[0.59]=1.40[0.17]$ Meas $P-0.51 \times 10^{-1}[0.25] ; \mathrm{r}^{2}=0.78 ; \mathrm{n}=22 ; \mathrm{p}<0.001$, Type 1 error, standard error terms given in square brackets); (B) calcite (Pred $C[0.54]=0.65[0.16]$ Meas $C+5.86 \times 10^{-2}[0.14] ; r^{2}=0.32 ; n=38 ; p<$ 0.001 , Type 1 error); and (C) combined organic matter and calcite $\left(\right.$ Pred $(P+C)[0.31]=1.22[0.05]$ Meas $(P+C)-5.47 \times 10^{-1}[0.12] ; \mathrm{r}^{2}=$ $0.97 ; \mathrm{n}=22 ; \mathrm{p}<0.001$, Type 1 error). Organic carbon production is overestimated and calcification is underestimated at high growth rates. In absolute terms, the closest slope to the 1:1 line was for total carbon fixation 
values. Photosynthesis predictions were closest to the measured values at low growth rates, and they exceeded the measured values at highest growth rates. Predictions of calcification showed an opposite trend; they were close to measured values at low growth rates, and generally lower than measured values at high growth rates. In absolute terms, the best matches between measured and predicted carbon fixation rates were observed when total carbon fixation (inorganic plus organic) was considered. It is clear that without knowledge of the decoupling between photosynthesis and calcification, prediction of the individual rates from standing stock and growth rate will be difficult.

The strategy to vary the $C / P$ ratio as a function of growth has interesting ecological implications. Terminating calcification when growth is extremely lightlimited may be an adaptive strategy since this mainly would occur at the base of the euphotic zone. Potentially lethal sinking of light-limited cells could be minimized by maintaining a low specific density (i.e. slowing coccolith production at low growth rate). Provided the cell had another source of $\mathrm{CO}_{2}$, such as via carbonic anhydrase in chloroplasts, then shutting down calcification might not necessarily limit the photosynthetic carbon fixation.

The problem with this interpretation, however, is the observation of dark calcification (Paasche 1962, 1963 1964, Balch et al. 1992, Paasche \& Brubak 1994), where there obviously is no photosynthesis, which yields an infinitely high $C /$ Pratio. Calcifying aphotic cells would increase their sinking rate if they did not jettison their coccoliths. One explanation for this dichotomy between our results (suggesting decreasing calcification under decreasing light levels) and other batch culture results (clearly showing dark calcification) may be due to the culturing method. In our light-limited continuous cultures, the effective time scale for cells kept at the lowest light level was about 4 to $5 \mathrm{~d}$. In batch culture experiments, cells would be removed from a given light regime, and darkened for a 0.2 to 1 d incubation Under such conditions, the cellular energy stores might be sufficient to maintain calcification in complete darkness during the measurement. Lastly, there may be strain effects, too. Linschooten et al. (1991) did not observe dark calcification in Emiliania huxleyi (strain L from Oslo, Norway) kept on light-dark cycles, perhaps indicating tighter coupling between calcification and photosynthesis in this strain. Environmental factors controlling the $C / P$ ratio remain extremely relevant to understanding the overall physiological ecology of this ubiquitous coccolithophore species

Acknowledgements. Katherine Kilpatnck and Ian Gilbert helped in carrying out these experiments. The comments of 3 anonymous reviewers are greatly appreciated. The work was supported by the Office of Naval Research (N00014-91-J-
1048), NASA (NAGW 2426 and NAS5-31363) and NSF (OCE9022227, OCE-9311077, and OCE-9596167) to W.M.B. Support for E.F. was from the European Commission under contract EHUX MAS-CT92-0038. This is Bigelow Laboratory contribution number 96004

\section{LITERATURE CITED}

Balch WM, Holligan PM, Kilpatrick KA (1992) Calcification photosynthesis and growth of the bloom-forming coccolithophore, Emiliania huxleyi. Cont Shelf Res 12:1353-1374.

Bramlette M.N (1958) Significance of coccolithophorids in calcium carbonate deposition. Bull Geol Soc Am 69:121-126

Broecker W, Peng TH (1982) Tracers in the sea. LamontDoherty Geol Obs, Columbia University, New York

Dong LF, Nimer NA, Okus E, Merrett MJ (1993) Dissolved inorganic carbon utilization in relation to calcite production in Emiliania huxleyi (Lohmann) Kamptner. New Phytol 123:679-684

Droop M (1967) A procedure for routine purification of algal cultures with antibiotics. Br Phycol J 3:295-297

Eppley RW, Dyer DL (1965) Predicting production in light limited continuous cultures of algae. Appl Microbiol 13 $833-837$

Eppley RW, Rogers JN, McCarthy JJ, Sourna A (1971) Light/ dark periodicity in nitrogen assimilation of the marine phy toplankters Skeletonema costatum and Coccolithus huxleyi in N-limited chemostat culture. J Phycol 7:150-154

Fernandez E, Boyd P, Holligan PM. Harbour DS (1993) Production of organic and inorganic carbon within a large scale coccolithophore bloom in the north Atlantic Ocean. Mar Ecol Prog Ser 97: 271-285

Fernandez E, Fritz JJ, BaIch W (1.996) Growth-dependent chemical composition of the coccolithophorid Emilianla huxleyı in light-limited chemostats. J Exp Mar Biol Ecol (in press)

Fritz JJ, Balch WM (1996) A continuous culture study of Emiliania huxleyi: determination of coccolith detachment rates and the relevance to cell sinking rates. J Exp Mar Biol Ecol (in press)

Holm-Hansen O, Lorenzen CJ, Holmes RW, Strickland JDH (1965) Fluorometric determination of chlorophyll. J Cons Perm Int Explor Mer 30:3-15

Keller MD. Selvin RC, Claus W, Gullard RRL (1987) Media for the culture of oceanic ultraphytoplankton. J Phycol 23: 633-638

Ketchum BH, Lillick L, Redfield AC (1949) The growth and optimum yields of algae in mass culture. J Cell Comp Physiol 33:267-279

Ketchum BH. Redfield AC (1938) A method for maintaining a continuous supply of manne diatoms by culture. Biol Bull Mar Biol Lab, Woods Hole 75;65-69

Lewin JC (1962) Calcification. In: Lewin RA (ed) Physiology and biochemistry of algae. Academic Press, New York, $p$ $457-465$

Linschooten $C$, van Bleijswijk JDL, van Emburg PR, de Vrind JPM, Kempers ES, Westbroek P, de Vrind-de Jong EW (1991) Role of the light-dark cycle and medium compositron on the production of coccoliths by Emilania huxleyt (Haptophyceae). J Phycol 27:82-86

Lohmann $\mathrm{H}$ (1908) On the relationship between pelagic deposits and marine plankton. Int Rev Ges Hydrobiol Hydrogr 1:309-323 (in German)

McIntyre A, Be AWH (1967) Modern coccolithophoridae of the Atlantic Ocean I. Placoliths and cyrtoliths. Deep Sea Res 14:561-597 
Milliman JD (1993) Production and accumulation of calcium carbonate in the ocean: budget of a nonsteady state. Global Biugeochem Cycles 7:927-957

Nimer NA, Merrett MJ (1992) Calcification and utilization of inorganic carbon by the coccolthophorid Emllania huxleyı Lohmann. New Phytol 121:173-177

Nimer NA, Merrett MJ (1993) Calcufication rate in Emilhania huxleyt Lohmann in response to light, nitrate and availabıllty of inorganic carbon. New Phytol 123: $673-677$

Paasche E (1962) Coccolith formation. Nature 193:1094-1095

Paasche E (1963) The adaptation of the carbon-14 method for the measurement of coccolith production in Coccolithus huxleyi. Physiol Plant 16:186-200

Paasche E (1964) A tracer study of the inorganic carbon uptake during coccolith formation and photosynthesis in the coccolithophorid Coccolithus huxleyi. Physiol Plant suppl 3:1-82

Paasche E. Brubak S (1994) Enhanced calcification in the coccolithophorid Emiliania huxleyi (Haptophyceae) under phosphorus limitation. Phycologia 33:324-330

Paasche E. Klaveness D (1970) A physiological comparison of coccolith-forming and naked cells of Coccolithus huxleyi Arch Mikrobiol 73:143-152

Parsons TR, Maita Y, Lalli CM (1984) A manual of chemical

This article was submitted to the editor and biological methods for seawater analysis. Pergamon Press Inc, New York

Quiroga O, Conzalez EL (1993) Carbonic anhydrase in the chloroplast of a coccolithophorid (Prymnesiophyceae). J Phvcol 29: 321-324

Sikes CS, Roer RD. Wilbur KM (1.980) Photosynthesis and coccolith formation: inorganic carbon sources and net inorganic reaction of deposition. Limnol Oceanogr 25:248-261

Sikes CS, Wilbur KM (1982) Functions of coccolith formation. Limnol Oceanogr 27:18-26

Steemann Nielsen E (1966) The uptake of free $\mathrm{CO}_{2}$ and $\mathrm{HCO}_{3}$ during photosynthesis of plankton algae with special reference to the coccolithophorid Coccolithus huxleyi. Physiol Plant 19:232-240

Stumm W, Morgan JJ (1981) Aquatic chemistry, 2nd edn. John Wiley and Sons, Inc. New York

Westbroek P, Brown CW, van Bleijswijk J, Brownlee C, Jan

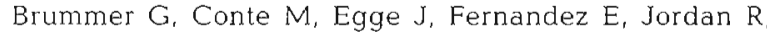
Knappertsbusch $M$, Stefels J, Veldhuis $M$, van der Wal $P$, Young J (1993) A model system approach to biological climate forcing. The example of Emiliania huxleyi. Global Planet Change 8:27-46

Yentsch CS, Menzel D (1963) Method for the determination of phytoplankton chlorophyll and phaeophytin by fluorescence. Deep Sea Res 10:221-231

Manuscript first recelved: June 13, 1995

Revised version accepted: July 26, 1996 